\title{
PRIMARY FALLOPIAN TUBE CARCINOMA: CASE REPORT
}

\author{
Syamala Onimi ${ }^{1}$, Usha Rani Godla ${ }^{2}$
}

\section{HOW TO CITE THIS ARTICLE:}

Syamala Onimi, Usha Rani Godla. "Primary Fallopian Tube Carcinoma: Case Report". Journal of Evolution of Medical and Dental Sciences 2015; Vol. 4, Issue 22, March 16; Page: 3907-3911,

DOI: $10.14260 /$ jemds $/ 2015 / 562$

\begin{abstract}
Primary fallopian tube carcinoma is a rare gynecological carcinoma when compared to ovarian malignancies. Fallopian tube carcinoma accounted for 0.3 per cent of all cancers of the female genital tract. Fallopian tube carcinomas are frequently involved in secondarily from other primary sites, most often the ovaries, endometrium, gastro intestinal tract and breast. We, came across one rare case of primary fallopian tube carcinoma presented on post-menopausal bleeding, with adnoxal mass for which laparotomy was done diagnosed to have primary fallopian tube carcinoma intra operatively.
\end{abstract}

KEYWORDS: Fallopian tube carcinoma, primary and secondary

INTRODUCTION: Historically carcinoma of the fallopian tube accounted for 0.3 per cent ${ }^{1}$ of all the cancers of the female genital tract. In histologic features and behaviour fallopian tube carcinoma is similar to ovarian cancer, thus the evaluation and treatment are essentially the same.

Classic triad of symptoms and signs associated with fallopian tube cancer are:

a. Prominent watery vaginal discharge hydrops tubae profluens. ${ }^{1}$

b. Pelvic pain ${ }^{1}$ and

c. Pelvic mass. ${ }^{1}$

For diagnosis of primary tubal carcinoma of both ovaries and the uterus ${ }^{2}$ should appear normal on gross examination.

Sri Ramachandra Medical College and Research Institute is a tertiary care and referral institute with annual total deliveries of over 5000. We came across a rare case of primary fallopian tube carcinoma presented with post-menopausal bleeding.

DETAILS OF THE CASE: A 48 year old postmenopausal woman of P2L2 attained menopause eight year ago. With known diabetes history and on oral hypoglycemic agents. The patient presented to the OPD with postmenopausal bleeding of one month duration. Clinical examination revealed normal size uterus with right adnexal mass of $5 \times 5$ centimetres. Basic blood investigations are within normal range/limits. PAP smear was taken which was normal and negative for malignancy.

Her CA-125 was 41; transvaginal ultrasound was done and is suggestive of normal uterus with right adnexal mass of $3.7 \times 3.8$ centimetres. Along with these preliminary tests endometrial aspiration was also performed and which came as negative for any malignancy. In view of elevated CA-125 and right adnexal mass with a provisional diagnosis of ovarian tumour, the patient was taken up for laparotomy. Intra-operatively, uterus was normal, left tube and ovary were normal, right ovary was normal but the right was enlarged and elongated with growth of $5 \times 5$ centimetres. Intraoperatively the specimen was sent for frozen section which came as primary serous carcinoma of the fallopian tube. Postoperatively the patient was planned for chemo therapy. 
DISCUSSION: Primary fallopian tube carcinoma is of epithelial origin frequently of serous histology. They are seen most frequently in the fifth and sixth decades with a mean age of 55 to 60 years. Women who have germline mutations in BRCA1 and BRCA2 ${ }^{3}$ or at substantially at higher risk for developing fallopian carcinoma. Therefore, prophylactic surgery in these women should include a complete removal of both fallopian tubes and along with the ovaries. Since fallopian tube carcinoma resembles ovarian carcinoma they have been treated in a similar fashion.

The overall five year survival for patients with epithelial tubal carcinoma is about 40 per cent. The reported five year survival rate for patients with stage-I disease is 65 per cent; Stage-II 50 to 60 per cent but it is only 10 to 20 per cent for patients with stages III and IV disease.

\begin{tabular}{|c|c|}
\hline Stage 0 & Carcinoma in situ (limited to tubal mucosa) \\
\hline Stage I & Growth is limited to the fallopian tubes \\
\hline IA & $\begin{array}{l}\text { Growth is limited to one tube with extension into the submucosa and/or } \\
\text { muscularis but not penetrating the serosal surface; no ascites }\end{array}$ \\
\hline IB & $\begin{array}{l}\text { Growth is limited to both tubes with extension into the submucosa and/or } \\
\text { muscularis but not penetrating the serosal surface; no ascites }\end{array}$ \\
\hline IB & $\begin{array}{l}\text { Tumor eithr stage IA or IB but with tumor extension through or onto the tubal serosa; } \\
\text { or with ascites present containing malignant cells or with positive peritoneal washings }\end{array}$ \\
\hline Stage II & Growth involving one or both fallopian tubes with pelvic extension \\
\hline IIA & Extension and/or metastasis to the uterus and/or ovaries \\
\hline IIB & Extension to other pelvic tissues \\
\hline IIC & $\begin{array}{l}\text { Tumor either stage IIA or IIB but with tumor extension through or onto the tubal serosa; } \\
\text { or with ascites present containing malignant cells or with positive peritoneal sashings }\end{array}$ \\
\hline Stage III & $\begin{array}{l}\text { Tumor involves one or both fallopian tubes with peritoneal implants outside of the } \\
\text { pelvis and/orpositive retroperitoneal or inguinal nodes. Superficial liver metastases } \\
\text { equals stage III. Tumor appears limited to the true pelvis but with histologically proven } \\
\text { malignant extension to the small bowel or omentum }\end{array}$ \\
\hline IIIA & $\begin{array}{l}\text { Tumor is grossly limited to the true pelvis with negative nodes but with histologically } \\
\text { confirmed microscopic seeding of abdominal peritoneal surfaces }\end{array}$ \\
\hline IIIB & $\begin{array}{l}\text { Tumor involving one or oth tubes with histologically confirmed implants of abdominal } \\
\text { peritoneal surfaces, none exceeding } 2 \mathrm{~cm} \text {. in diameter. Lymph nodes are negative }\end{array}$ \\
\hline IIIC & $\begin{array}{l}\text { Abdominal implants greater than } 2 \mathrm{~cm} \text {. in diameter and/or positive retroperitoneal or } \\
\text { inguinal nodes }\end{array}$ \\
\hline Stage IV & $\begin{array}{l}\text { Growth involving one or both fallopian tubes with distant metastases. If pleural } \\
\text { effusing is present, there must be positive cytology to be stage IV. Parenchymal liver } \\
\text { metastases equals stage IV }\end{array}$ \\
\hline
\end{tabular}

FIGO, InternationalFederation of Gynaecology and Obstetrics, from Berek JS, Hacker NF. Berek and Hacker's Gynaecologic Oncology. $5^{\text {th }}$ edition. Philadelphia, PA; Lippincott Williams \& Wilkins, 2010:494; adapted from FIGO Annual Report, Volume 26, International journal of Gynecology and Obstetrics 2006; 105:3-4. 


\section{CASE REPORT}

\section{REFERENCES:}

1. Jonathan S Berek, Berek and Novak's gynaecology, $15^{\text {th }}$ edition, published by Wolters Kluwer India private limited, Chapter \# 37, Ovarian fallopian tube and peritoneal cancer, Section VII page 1414-1416.

2. Saxena Bhati Bansal Gupta, Fallopian tube carcinoma - A case report, Journal of obstetrics and gynaecology of India, Volume 57, \# 1 January/February, 2007, Page 81-82.

3. Carolina Oliveila HalioDuarto et., Al., Small fallopian tube carcinoma with extensive upper abdominal dissemination: A case report, Journal of medical case reports, 2013, 7: 252.

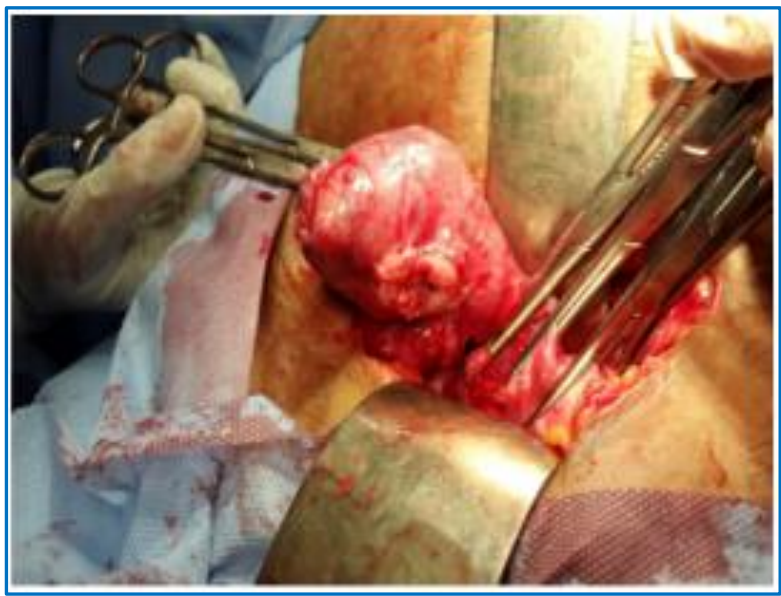

Figure 1: Growth involving in the right fallopian tube

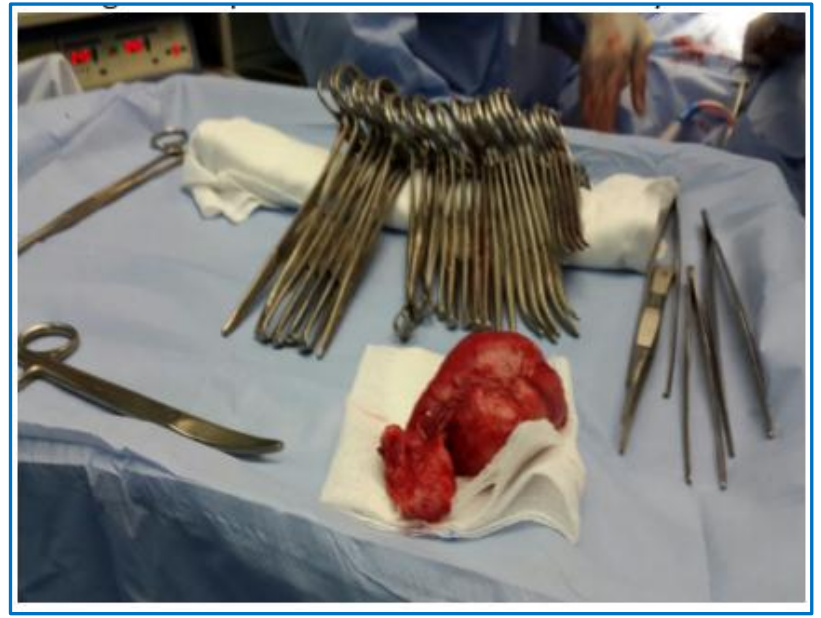

Figure 2: Growth in the right fallopian tube with normal ovary after the surgical procedure fallopian tube 


\section{CASE REPORT}

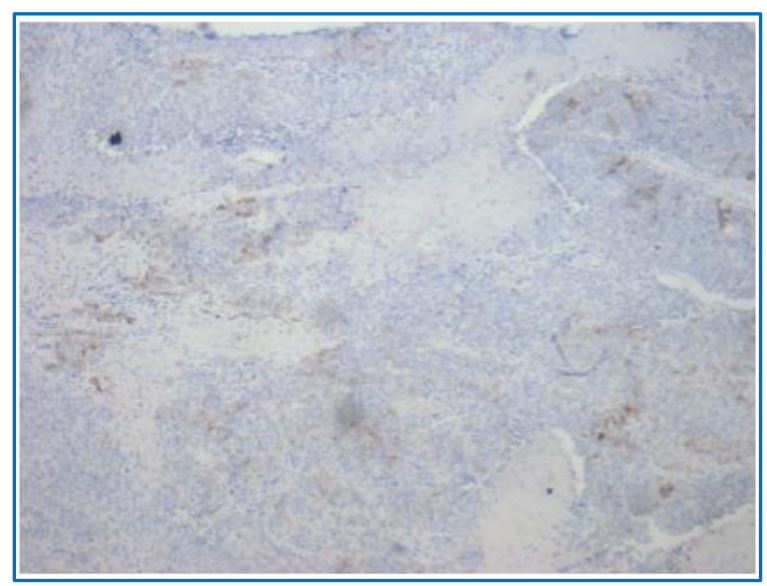

\section{Figure 3: Histopathological Staining of} the malignant tissue (CK7)

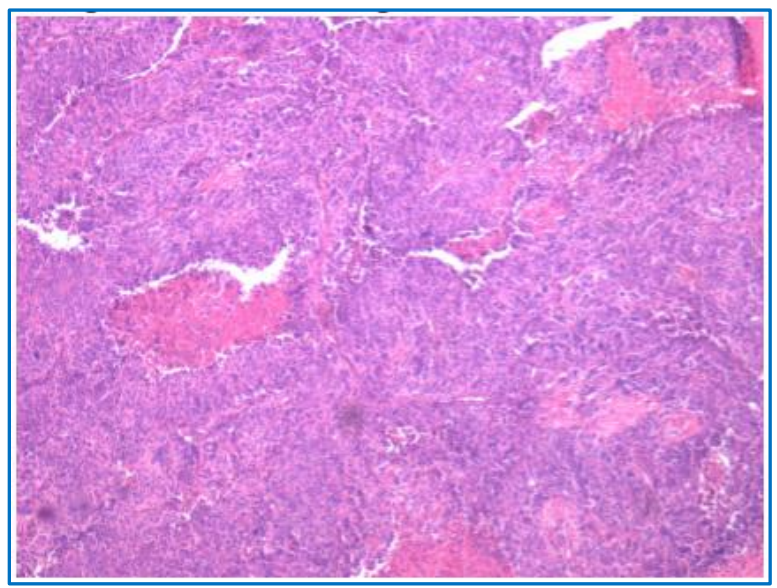

Figure 4: 40 times magnification of the tissue

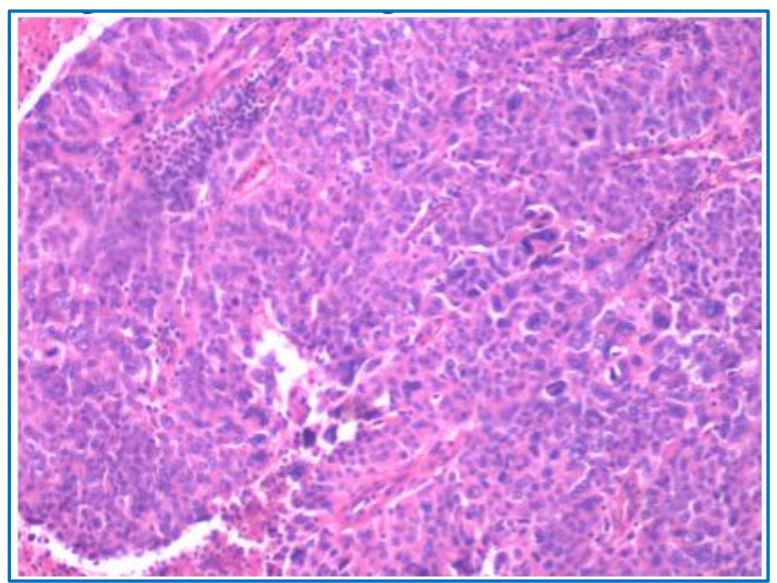

Figure 5:100 times magnification of the tissue 


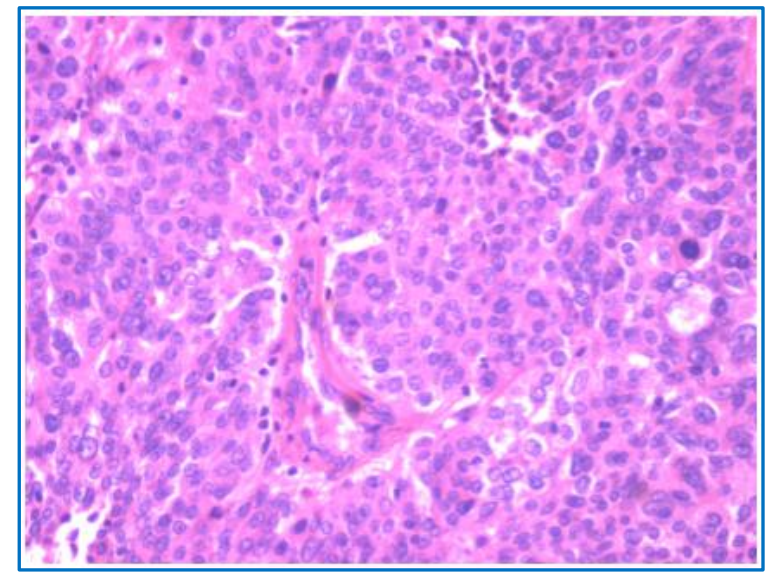

Figure 6: 200 times magnification of the tissue

\section{AUTHORS: \\ 1. Syamala Onimi \\ 2. Usha Rani Godla}

\section{PARTICULARS OF CONTRIBUTORS:}

1. Associate Professor, Department of Obstetrics \& Gynaecology, SRMC and RI, Porur, Chennai.

2. Professor, Department of Obstetrics \& Gynaecology, SRMC and RI, Porur, Chennai.

FINANCIAL OR OTHER COMPETING INTERESTS: None

\section{NAME ADDRESS EMAIL ID OF THE} CORRESPONDING AUTHOR:

Dr. Syamala Onimi, Associate Professor, Department of Obstetrics \& Gynaecology, SRMC and RI, Porur,

Chennai-600116, Tamil Nadu.

E-mail: syamalapitani@yahoo.com

Date of Submission: 31/02/2015. Date of Peer Review: 02/03/2015. Date of Acceptance: 04/03/2015. Date of Publishing: 16/03/2015. 